\title{
Corporate Governance Guideline Relevance To Maltese Family Public Interest Companies A Small State Perspective ${ }^{1}$
}

\author{
Baldacchino, Peter ${ }^{\mathrm{a} *}$, Cachia, Karl ${ }^{\mathrm{a}}$, Tabone, Norbert ${ }^{\mathrm{a}}$, Grima Simon ${ }^{\mathrm{a}}$, Bezzina Frank ${ }^{\mathrm{a}}$

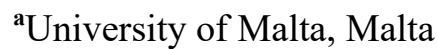 \\ ${ }^{\mathbf{b}}$ Malta Development Bank, Malta
}

\begin{tabular}{|c|c|}
\hline A B S T R A C T & A R T I C L E I N F O \\
\hline $\begin{array}{l}\text { The objectives of this paper are to investigate the relevance of } \\
\text { guidelines on good corporate governance (CG) to family public } \\
\text { interest companies (PICs) within the small state of Malta and to } \\
\text { recommend how existing guidelines may be improved and tailored } \\
\text { for such companies. An explanatory mixed-methods empirical } \\
\text { approach is adopted with a structured questionnaire being first } \\
\text { administered to } 17 \text { respondents in } 12 \text { PICs owned by different } \\
\text { families. This was then followed by semi-structured interviews with } \\
\text { the representatives of } 11 \text { of these PICs. Findings indicate that there is } \\
\text { a need for the existing guidelines to be improved for them to become } \\
\text { more in line with the needs of PICs which are characterised by } \\
\text { dominant family interests. In this respect, this paper recommends } \\
\text { possible principles and guidelines that may be used by the relevant } \\
\text { authorities either to improve the existing PIC guidelines or to issue a } \\
\text { new set of guidelines aimed specifically for family PICs. Given the } \\
\text { peculiarities of such companies, it is clear that the guidelines have to } \\
\text { contain elements that address the CG structure, such as the need to } \\
\text { formally document a family governance plan. Clearer guidance is } \\
\text { needed on the appointment and composition of the Board of } \\
\text { Directors, on the employment, conduct, compensation and } \\
\text { performance evaluation of managers, as well as on the composition of } \\
\text { the ownership of family PICs. Additionally, the paper concludes that } \\
\text { a relevant factor for family PICs in carrying out improvements to } \\
\text { their CG is that they continue to place more importance than other } \\
\text { PICs to their continued existence. }\end{array}$ & $\begin{array}{l}\text { This article was presented at } \\
\text { the 8th International OFEL } \\
\text { Conference on Governance, } \\
\text { Management and } \\
\text { Entrepreneurship. From } \\
\text { Corporations to Social } \\
\text { Entrepreneurs: } \\
\text { Exploring the Different Faces } \\
\text { of Social Innovation (April } \\
\text { 17th - 18th, 2020, Dubrovnik, } \\
\text { Croatia, Governance Research } \\
\text { and Development Centre } \\
\text { CIRU), Zagreb, pp. 2-24 }\end{array}$ \\
\hline
\end{tabular}

\section{INTRODUCTION}

Family businesses in Malta form the vast majority of the local business community (Farrugia, 2010; Zahra, 2017). Moreover, while studying family businesses may conjure up thoughts of "father and son" firms, some of the largest companies in Malta are family-run businesses (Farrugia, 2010).

The objectives of this paper are to investigate the relevance of the guidelines on good corporate governance (CG) to family public interest companies (PICs) in Malta and to recommend how 
existing guidelines may be improved and tailored to such family PICs. The study is conducted in Malta, a small island state in the European Union.

\subsection{DEFINITION OF 'CORPORATE GOVERNANCE'}

The Cadbury Committee (1992) defined CG as the "the system by which companies are directed and controlled" (Para. 2.5). According to Muscat (2007) and Farrugia (2010), this definition was later adopted by the Maltese Working Group on CG which was set up by the Malta Stock Exchange (MSE) in 2001. The definition was adopted because it was deemed to be concise and sufficiently wide in scope (Working Group on CG, 2001). In the same year, the Malta Financial Services Authority (MFSA) issued The Code of Principles of Good CG for Listed Entities ("the Code").

\subsection{THE CORPORATE GOVERNANCE FRAMEWORK IN MALTA}

There are four authoritative sources that crystallise the concept of CG in Malta. The root source is the law. According to Muscat (2007), recommendations for good CG often stem from existing principles of law. Moreover, the concept of CG tends to find its way in every aspect of company law (ibid.).

The other three sources that encapsulate CG were issued by the MFSA. These are the Manual for Directors of Investment Companies and Collective Investment Schemes (CISs) ("the Manual"), the Guidelines for Public Interest Companies (PIC) ("the Guidelines"), and the Code of Principles for Listed Entities. Each one targets specific types of companies. The Manual targets investment companies and CISs, the Guidelines target public interest companies, and the Code targets listed entities. Figure 1 illustrates the four sources of CG in Malta.

The three documents issued by MFSA constitute a framework for the promulgation of good governance practices in companies where the public interest is especially at stake. The documents issued for each category indicate the regulator's cognisance of the different CG needs of each entity, depending largely on whether entities have securities issued to the public or whether they are regulated.

\subsection{A FOCUS ON CORPORATE GOVERNANCE GUIDELINES}

The Manual and the Code are two very specific documents that target particular types of public interest entities. The Manual is geared towards addressing the technical setup of investment companies (MFSA, 2014) whilst the Code targets listed entities (MFSA, 2001).

On the other hand, the Guidelines take a wider view. While steering away from the "comply or PAGE 15| Journal of Corporate Governance, Insurance, and Risk Management | 2020, VOL. 7, Series. 2 
explain" principle in the Code (MFSA, 2001), the Guidelines target entities that are not necessarily listed. These include insurance companies, banks and other companies having publicly issued debt securities

\begin{tabular}{|c|}
\hline Corporate \\
Governance Manual \\
for Directors of \\
Investment \\
Companies and \\
Collective Investment \\
Schemes \\
\hline
\end{tabular}

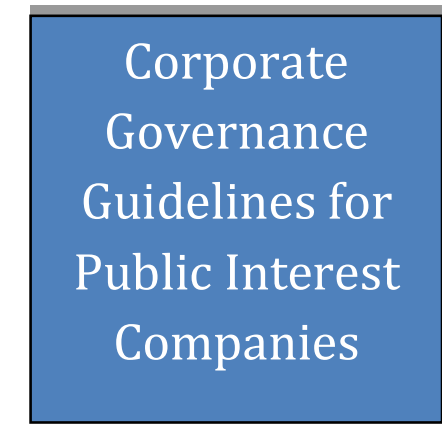

Company Law

Figure 1 - The Corporate Governance Sources for Maltese PICs

This study focuses on the relevance of CG guidelines to family public interest companies in Malta.

\subsection{DEFINITION OF 'FAMILY COMPANY'}

One of the difficulties is to define a family business, especially in the Maltese context. In the absence of an internationally recognised, legally binding definition of what constitutes a 'family business' (Kraiczy, 2013; Zahra, 2017), defining what constitutes a family company for the purposes of the study is important because it will impact the interpretation of the results.

Family involvement in a company is the first condition necessary for a firm to be a family business (Chrisman, J. J. \& Holt, D. T., 2016, cited in Chrisman J. J. et al, 2018). In fact, Hnilica and Maechek (2015) argue that there are three elements that constitute the making of a family business: ownership representation which refers to the percentage of ownership held by one family, management representation which refers to the degree to which family members occupy senior management positions, and board representation which refers to the degree to which family members occupy the Board.

All three elements measure the degree to which an interconnected group of individuals can influence the decision-making process of a business. Ownership of the majority voting rights gives effect to the 
full power of influence, that is, control. On the other hand, where the family holds a minority share of the ownership and the remaining portion is dispersed, influence can manifest itself to a lesser degree through board and management representation. In larger firms, it is possible for family members to own less than a majority of the shares and elect a board of directors that supports their interests (Tagiuri \& Davis, 1996).

For the purposes of this study, a family-controlled company is defined as one having more than $25 \%$ of the share capital held by the founding family or next generation families, with two or more family directors. A family-influenced company is defined as having less than $25 \%$ of the share capital held by the family and two or more family directors (Baldacchino et al, 2019).

\subsection{DEFINITION OF 'PUBLIC INTEREST COMPANY'}

The Guidelines define a PIC as: (i) a regulated company excluding investment companies and CISs, or (ii) a company that has issued debt securities to the public and whose securities are not admitted to listing on a recognised investment exchange, or (iii) a government-owned entity established as a limited liability company. Whilst the definition in the Guidelines includes government-owned companies, it excludes companies whose securities are listed, ostensibly because listed companies are expected to adhere to the Code on good CG. Considering that listed entities form an integral part of the definition of a PIC whilst government-owned companies are not family-owned, a working definition of a PIC shall include any of the following three types of companies:

(i) Companies whose transferable debt or equity securities are listed on a regulated stock exchange;

(ii) Credit institutions, whether listed or not;

(iii) Insurance undertakings, whether listed or not.

\subsection{NEED FOR THE STUDY}

If family businesses form the majority of the local business community (ibid.) and the governance of a family company is more complex than the governance of a company with no family involvement (Cadbury, 2000), the Guidelines currently in place may be taking a one-size-fits-all approach that does not recognise the peculiar needs of family companies. There may be a gap which the current CG framework is not addressing.

A preliminary review of foreign literature pointed towards the codification of a set of principles of $\mathrm{CG}$ that are specific to family businesses. For example, one of the first initiatives was taken jointly by a group of German organisations - INTES Family Business Academy by PwC, the Family PAGE 17| Journal of Corporate Governance, Insurance, and Risk Management | 2020, VOL. 7, Series. 2 
Business Network, and Die Familien Unternehmer. These entities co-jointly issued a Governance Code for Family Businesses in 2004 which is still being updated periodically. (INTES, FBN \& Die Familien Unternehmer - ASU, 2004).

A similar initiative was undertaken by the European Confederation of Directors' Associations which issued a set of CG Guidance and Principles for unlisted companies in Europe (ecoDa, 2010). Similarly, in 2011, the International Finance Corporation (IFC) published a Governance Handbook meant specifically for family businesses. In 2015, Riinvest Institute continued this trend and published a Governance Guide for Family-Owned Businesses.

Some of the principles in these guides address issues in family-controlled entities such as the relationship between family shareholders and minority shareholders, unfair prejudice, controlling interests versus the achievement of performance, barriers to entry, and family governance initiatives (Cadbury, 2000; Farrugia, 2010; IFC, 2011). These issues are expected to feature in the CG reality of family PICs in Malta.

\section{THE DISTINCTIVE ATTRIBUTES OF FAMILY COMPANIES}

Cadbury (2000) claimed that it is necessary to recognise that the governance of family companies is more complex than the governance of companies with dispersed ownership. This is because of the distinctive features of family companies.

\subsection{CONCENTRATION OF POWER}

Tagiuri and Davis (1996) identified various attributes of the family company. One of the most distinctive features is that individuals in a family organisation can take on simultaneous roles in three spheres of interest: as family members they take an interest in the welfare of the family; as owners they are primarily interested in a return on investment; as managers they are focused on the day-today running of the business.

This characteristic often results in individuals taking on multiple, overlapping roles in a family business (Hirsch, n.d.). The upside is rapid and effective business decision-taking because the overlapping roles tend to centralise decision-making (Tagiuri \& Davis, 1996). A dominant leader may also instil healthy growth and business continuity which may be beneficial both to family interests and the public at large. In this context, evidence from Norway also suggested that ownership concentration positively affects a company's growth and profitability (Mishra, Randoy, \& Jenssen, 2001). This was later confirmed by Chen (2012).

PAGE 18| Journal of Corporate Governance, Insurance, and Risk Management | 2020, VOL. 7, Series. 2 
Nonetheless, the concentration of power may also result in conflicts of interest when family members pursue family interests rather than business interests (Daspit, et al. 2017; Tagiuri and Davis, 1996). Baldacchino et al (2019) argued that measures should be established to promote beneficial motives and eliminate detrimental, non- financial drivers that result in conflicts of interest. Concentration of power and overlapping roles often result in permanence of office (ibid.). There is also a tendency for family members to stick to their chair or executive role for an extended period (ibid.). For example, a characteristic of founding family owners is precisely the reluctance to accept professional managers capable of addressing new challenges (Mishra, Randoy, \& Jenssen, 2001).

\subsection{EMOTIONAL TIES}

Emotions often surface more easily between family members than between non- related individuals. This is because family members share a common history and the perceptions or impressions between them are unconscious and well ingrained (Tagiuri \& Davis, 1996). This leaves more possibility for stronger emotions to be displayed among family members. These complex, deep-rooted ties may facilitate or complicate working relationships between family members (ibid.).

\subsection{COVERT COMMUNICATION LINES}

Due to the emotional ties and shared experiences, family members can exchange information more efficiently and with greater privacy (ibid.). The interaction in the family system does not typically follow an overt protocol and needs to be understood from the behaviour and attitudes of the family members (Hirsch, 2013). Family members may use special phrases, expressions and non-verbal language (Kepner (1983) cited in Hirsch (2013); Tagiuri \& Davis, 1996). Covert lines of communication may lead to quicker decisions and may also act as an efficient dispute resolution tool (Taguri \& Davis, 1996).

\subsection{ILLIQUIDITY OF SHARES}

Mustakallio (2002) noted that the shares in a family business are generally illiquid. Similarly, Baldacchino et al (2019) explained that founding families are unlikely to dispose of their ownership. Share transfers in a family business setting are not the norm and tend to be triggered by exceptional events such as an injection of capital, inheritance, and family disputes (Mustakallio, 2002).

\subsection{PROPENSITY TO DISTRIBUTE DIVIDENDS}

Thomas (2001) as cited by Mustakallio (2002) noted that in large, publicly-traded companies, the shareholders' return on investment comes from a combination of share price gains and dividends. Notwithstanding, in the case of family companies where there is no active market for shares, the PAGE 19| Journal of Corporate Governance, Insurance, and Risk Management | 2020, VOL. 7, Series. 2 
financial return to the owners comes largely from dividends. In the absence of an active market, different interests may place pressures on scarce financial resources through dividend distributions that may not always be appropriate in the circumstances.

For instance, family shareholders may have different objectives depending on the type of position they hold. A family shareholder who also holds a managerial position with a regular salary would naturally be inclined to resist the distribution of dividends to the detriment of other minority shareholders (Riinvest Institute, 2015). On the other hand, family and non-family shareholders not involved in the management of the company will naturally push for the distribution of dividends (ibid.).

\subsection{WEAKNESSES IN FAMILY COMPANIES}

The inherent characteristics of family companies give rise to certain defects that are only apparent in family companies. These weaknesses include suppressed corporate growth, agency

problems between shareholders, disparities between family and non- family members and conflict.

\section{Suppressed Growth}

The overlap of executive and non-executive roles and the permanence of family members indicate a predisposition towards family interests as opposed to value creation (Le-Breton-Miller \& Miller, 2009). This is because the retention of family control may take precedence over corporate growth. The consequential effects of the overlapping roles were also echoed by Baldacchino et al (2019) who identified the pursuit of control and non-economic goals as a characteristic of Maltese family companies.

Similarly, the illiquidity of family shares, the absence of a share transfer mechanism, and the family's reluctance to release its equity harms business operations and growth prospects when additional capital is required (Baldacchino et al, 2019). Mustakallio (2002) similarly explained that there is a trade-off between the need for the company to increase its capital in pursuance of a healthy growth strategy and the family's interest to retain control. The latter comes at the expense of the former (Jain \& Shao, 2015).

\section{The Principal-Principal Agency Problem}

Several researchers argued that the most important agency problem in large companies is not the Berle and Means (1932) agency conflict between outside investors and managers, but the conflict PAGE 20| Journal of Corporate Governance, Insurance, and Risk Management | 2020, VOL. 7, Series. 2 
between non-controlling investors and controlling family shareholders that can dominate managers (Cacciotti \& Ucbasaran, 2017; Morck \& Yeung, 2003; Shleifer \& Vishny, 1997; Yeh, Lee, \& Woidtke, 2001). This is likely to result in the family taking advantage of the company's resources for its personal interest at the expense of non-controlling interests.

\section{Disparity among Family and non-Family Members}

Family companies have a reputation for exhibiting favoritism toward family members (IFC, 2011; Lee, 2006 cited in Daspit et al, 2018). In a setting where the family company seeks to recruit human resources for its expansion, family members may be primarily interested in securing jobs for their relatives rather than attracting talent on a meritocratic basis (Debicki, 2017). This creates a disparity between the corporate needs of the company and the family interest.

The unequal treatment of family and non-family members may also be displayed post-recruitment. Daspit et al. (2018) noted that as the family company grows and hires non-family members, there is often a clear and pronounced distinction between family and non-family members in the organisation. This may lead to the unequal treatment of the two groups (IFC, 2011; OECD, 2015), also conceptually known as bifurcation bias (Verbeke \& Kano, 2012). The desired outcome is to lock in family control (Morck \& Yeung, 2004).

In this respect, Baldacchino et al. (2019) explained that, for the sake of good governance, family members seeking to occupy roles within a family company should not be given an unfair advantage over non-family individuals. By the same token, there should be no prejudice against family members owing to their family interest (ibid.).

\section{Disputes and Family Conflict}

Several researchers have claimed that there is fertile ground for disputes in family companies. Family relations and emotional ties may lead to disputes at some point in time (Baldacchino et al., 2019; Morck \& Yeung, 2004; Sarbah \& Xiao, 2015). A situation where non-family employees, managers, and directors are not privy to the communication lines of family members is likely to result in uninformed decisions that undermine accountability and good governance (Tagiuri \& Davis, 1996).

Moreover, different factions within the family may also be present. In this context, Cacciotti and Ucbasaran (2017) noted that the participation of an increased number of family members in the PAGE 21| Journal of Corporate Governance, Insurance, and Risk Management | 2020, VOL. 7, Series. 2 
company's ownership results in greater diversity and reduces the ability of the family to exert a unified drive. The increased complexity in family ownership is most notably attributed to the decomposition of the founder family across subsequent generations over time (Zellweger \& Kammerlander, 2015).

There is also a greater risk of conflict between family shareholders and minority shareholders (KPMG, 2010). Conflicts over investment, capital, pay-out decisions, and share transfers are also common in family businesses (Mustakallio, 2002). Therefore, there is a high probability that conflict, in some form or another, will dent good CG in family companies.

\subsection{GOVERNANCE IN FAMILY COMPANIES}

\section{Composition of the Board}

Baldacchino et al. (2019) claimed that a suitable proportion of non-family independent directors is likely to contribute towards transparency and accountability in Maltese family businesses. Participants in their study mostly agreed that there is a positive correlation between the Board's independence and financial performance. The contribution of independent directors is also highlighted in the Principles of $\mathrm{CG}$ published by the Organisation for Economic Cooperation and Development (OECD, 2015). Similarly, the Governance Guide for Family-Owned Businesses published by Riinvest Institute (2015) recommends that "for a company to be successful in the long run, it should establish a strong and independent board" (p.14). Excessive family involvement at board level restricts the Board's ability to function effectively (Baldacchino et al, 2019; Goh, Rasli \& Khan, 2014).

Despite these observations, Baldacchino et al. (2019) also noted that in the Maltese context, blood is thicker than water. Family companies in Malta are not likely to appoint anyone who is resistant to family influence. This may lead to favouritism towards family members (Debicki et al, 2017; Lee, 2006 cited in Daspit et al, 2018) and a principal-principal agency problem (Cacciotti \& Ucbasaran, 2017; Morck \& Yeung, 2003; Shleifer \& Vishny, 1997; Yeh, Lee, \& Woidtke, 2001) where family interests run counter to the company's and other stakeholders' interests.

The importance of non-family directors is perhaps clearer in a family dispute, where independent directors may act as mediators. This is, however, not always possible, and conflicts may have to be resolved at other junctures (Baldacchino et al, 2018).

\section{The Chief Executive Officer}

When a family company is run by the first generation of family members, it is most likely that the PAGE 22| Journal of Corporate Governance, Insurance, and Risk Management | 2020, VOL. 7, Series. 2 
post of CEO will be occupied by the most senior family member. In this circumstance, there tends to be a concentration of power in one family member (Farrugia, 2010). In the case of family companies who are no longer led by a dominant figure but are instead being directed by the second or third generation of family members, Farrugia (2010) also noted that bringing in a non-family CEO would help to professionalise the company's senior management.

In much the same vein, Baldacchino et al. (2019) found that in the Maltese context the post of CEO needs to be independent from the family, especially if a chairperson is a family member. The main argument is that conflicting interests are more likely to arise when the two roles overlap, echoing the arguments of Daspit et al. (2017) and Tagiuri and Davis (1996). Baldacchino et al (2019) also points out that it is common to have a chairperson's role occupied by a family member since the role is nonexecutive.

Baldacchino et al. (2019) highlighted that having a family CEO is likely to put the Board in an uncomfortable position if performance is not satisfactory, especially if the CEO has a direct relationship with the members of the Board. Moreover, the CEO is likely to display a lenient attitude towards family-related management team members (Baldacchino et al, 2018).

It is acknowledged that certain senior management positions require skills which the controlling family might not have. Professional education and qualifications are necessary to ensure that competent individuals are appointed in senior management roles (ibid.).

This might not be easily recognised by the family members who will most likely try to fill in such posts as a means of entitlement towards the business. There is a trade- off between the family's entitlement to the business and the creation of value for the company (Farrugia, 2010) because conflicts may arise between the family's interest and the business' interest (Lansberg, 1983). There is also a trade-off between the family's interest and the public interest (Baldacchino et al, 2019).

Notwithstanding these observations, evidence provided by Braun and Sharma (2007) shows that the duality of the chair and CEO positions does not affect a company's performance. More specifically, it is noted that the relationship between duality and performance is contingent on the family's degree of ownership in the company. The lower the family's ownership stake, the more benefits are derived from separating the two roles (ibid.).

Whether or not the chair or CEO positions are occupied by family members, the values that these members can bring to the business cannot be ignored. The loyalty, enthusiasm (Donnelley, 1988), PAGE 23| Journal of Corporate Governance, Insurance, and Risk Management | 2020, VOL. 7, Series. 2 
and firm-specific knowledge (Farrugia, 2010) of family members are unlikely to be matched by independent individuals.

\section{The Family Constitution}

The family constitution, also known as the 'family charter' or 'protocol', is a collective agreement which contains the rights and duties of those interested in the family's wealth. The family constitution lays down the company's family mission and outlines how the family goes about adhering to its mission and values in its business operations (IFC, 2011). The family constitution defines the roles, responsibilities, relationships, composition, and powers of decision-making bodies (Taylor Wessing, 2014). The constitution would typically contain the following elements: mission statement, values and vision; family-constituted bodies; board of directors; senior management; relationships between the family bodies, the Board and senior management; and policies regarding family issues including employment, share transfers, and succession planning (Nixha et al, 2015).

The objective of the family constitution is to document how to maintain a good relationship between the family members and the family-constituted bodies around the company (Taylor Wessing, 2014). It might be opportune to ratify the family constitution at a time when there is stability within the company, probably when the founding family is still at the helm (KPMG, 2010).

Even though small companies may find it more convenient to work with an unwritten set of procedures, formally documenting the family constitution might become essential to the performance of the company as it grows larger (IFC, 2011). There is no blueprint for properly designing a family constitution that is applicable to all family companies (ibid.). Regardless, a properly formulated family constitution is expected to deal with subjects such as the family's vision for the future, the family's mission statement, the functioning of family bodies, family members' employment policies, and share transfers, amongst others (Taylor Wessing, 2014).

\section{Family-Constituted Bodies}

Members of the family can meet and discuss family matters in a structured way. Family members often express themselves in family meetings (Weiste, 2013). The need for family members to meet and discuss depends on the size of the company. Meetings may take place informally when there are a limited number of family members. As the family members increase, the need to formalise meetings might arise. In this context, Mustakallio, Autio and Zahra (2002) noted that family meetings tend to be more effective in large family companies. There are different types of bodies that families can establish to formalise family meetings, including the Family Assembly, the Family Council, and the Family Office.

PAGE 24| Journal of Corporate Governance, Insurance, and Risk Management | 2020, VOL. 7, Series. 2 


\section{Family Assembly}

A family assembly is a meeting where family members discuss matters which concern them as owners (Neubauer \& Lank, 1998). Family assemblies deal with issues such as approving the vision and values of the family, family employment, compensation and the election of family members to participate in other governance bodies (Farrugia, 2010).

A family assembly is established when the family business becomes more complex and should be composed of both managing and non-managing family members (ibid.). The meetings are usually chaired by the most senior person in the family (IFC, 2011). Family assemblies are deemed to be very important to prevent and remediate conflicts between family members, especially during an inter-generational change of hands (Farrugia, 2010). In this context, family assemblies can also enable the process of 'transgenerational entrepreneurship' which a family undertakes to develop entrepreneurial mindsets across subsequent generations (Habbershon et al., 2010 cited in Zellweger, Nason, \& Nordqvist, 2011).

\section{Family Council}

A family council is a governing body that links the family with the company's governance organs and senior management (IFC, 2011). The members of a family council are elected from the family assembly (ibid.). The functions of a family council include nominating members for representation in the Board, maintaining the family constitution and documenting the vision and values of the family (ibid.). Following an election process, the council should be composed of the most senior family representatives with the relevant qualifications and experience, whether or not they are directly linked to the family company (Farrugia, 2010).

A family council should be chaired by an individual with the necessary experience. A record of the council's meetings should also be kept (ibid.). Similarly to family assemblies, family councils can serve to prevent and resolve family conflicts (Brenes, Madrigal \& Requena, 2011). It can also serve as an ideal venue for training the next generation of family directors and senior managers (Weiste, 2013).

\section{Family Office}

A family office is a separate body which is distinct from the family and the business. A family office is usually composed of independent professional managers who are tasked to provide advice on technical issues such as financial planning, wealth management and compliance (IFC, 2011). A family office is usually overseen by the family council (ibid.). Several wealthy families are likely to request the services of a family office: in this respect, family offices are mostly applicable to very PAGE 25| Journal of Corporate Governance, Insurance, and Risk Management | 2020, VOL. 7, Series. 2 
wealthy families and therefore not necessarily relevant in the Maltese context. (Baldacchino et al, 2019)

\section{METHODOLOGY}

\subsection{RESEARCH TOOL}

A mixed methodology was selected for the study because it is a means to achieve the benefits of two different methodologies. Creswell and Piano Clark (2011) highlight that in a mixed research methodology, both quantitative and qualitative data are collected, analysed separately, and then integrated, either concurrently or sequentially, to address the research questions. This aims to address the deficiencies in both quantitative and qualitative methodologies (Creswell, 2015).

A structured questionnaire was used that contained close-ended questions in the form of a Likert scale ranging from 1 to 5 . The close-ended questionnaire was designed on CG principles for family companies emanating from the literature review. A semi- structured interview schedule that contained open-ended questions was also used. The open-ended questions in the interview schedule were designed on the Guidelines issued by the MFSA.

\subsection{SAMPLE POPULATION}

A purposive sampling technique was used to reach the research objectives. This technique requires a researcher to apply judgement to select the appropriate research participants. In this respect, experts in the field of CG ('Experts') and company secretaries ('Cosec's) of family PICs were selected as the target population for this study. Twenty-six potential Experts and Cosecs were identified.

Experts consisted of representatives from regulatory authorities, government bodies, academics, lawyers, and ex-company secretaries. Relevant contacts were sourced from publicly available information.

Cosecs consisted of company secretaries acting for family PICs. A list of companies was extracted from the MSE publicly traded list, including MSE Prospects. A list of insurance undertakings and credit institutions was also extracted from the MFSA- authorised list of service providers.

Cosecs were identified through a search performed on the database of the Malta Business Registry. Relevant details were also available on the MSE's website, the Maltese Council of Notaries' website, and corporate websites

PAGE 26| Journal of Corporate Governance, Insurance, and Risk Management | 2020, VOL. 7, Series. 2 


\subsection{DATA ANALYSES}

Quantitative data generated from the Likert scale questions of the questionnaire were analysed using IBM SPSS Statistics. The rating scores ranged from 1 to 5 , where 1 corresponded to 'Strongly Disagree' and 5 corresponded to 'Strongly Agree'. Therefore, higher rating scores indicated a higher level of agreement with a particular statement. The mean score, median score, and standard deviation were calculated for each statement of the two groups of respondents. The ratings of the two groups were analysed in descending order of average Expert agreement.

Qualitative data was primarily collected through open-ended questions in the interview schedule. Additionally, qualitative data was collected through a 'comments' section inserted in the Likert scale questionnaire. Additional feedback on the Likert scale questions was also requested during the faceto-face interviews. The data was analysed by evaluating the transcribed data and identifying key themes and concepts.

\subsection{RESEARCH LIMITATIONS}

Seventeen participants responded to the questionnaire, of which six were unwilling to be interviewed or did not respond to the invitation. Obtaining the contact details of some respondents proved to be difficult and some company representatives cited the General Data Protection Regulation as restricting them from providing the necessary details.

Cosecs were sub-categorised into three groups for the purpose of explaining the limitations of the research. The following are the sub-categories:

(i) Lawyers working as sole practitioners;

(ii) Lawyers employed with law firms; and

(iii) Company secretaries employed with family companies (most of whom were also lawyers).

Sole practitioners and professionals employed with a law firm gave more candid replies and therefore seemed less biased than family-employed Cosecs. In this respect, some family-employed Cosecs were very defensive in their replies. The replies given by family-employed Cosecs were, in some instances, a recital of the company's CG formula and a reflection of the company's system.

\section{FINDINGS AND DISCUSSION}

\subsection{THE FAMILY GOVERNANCE PLAN}

PAGE 27| Journal of Corporate Governance, Insurance, and Risk Management | 2020, VOL. 7, Series. 2 
Documenting the family's vision, mission, future share transfer plans, and working relationships vis$\grave{a}$-vis the continued growth of the family's wealth through a family governance plan would serve to improve the stability and continuity of the company (KPMG, 2010). It is also seen as a positive measure to enhance the CG of a PIC owned by family interests because having a documented plan of action is a source of stability.

In fact, the second measure most agreed-to related to documenting the family's principles, vision, and mission in a formal and transparent manner. Experts and Cosecs agreed that formally documenting the family's vision and mission with respect to the business would enhance CG.

The time at which the document is formulated is crucial. The document needs to be formulated at the time when the family and the company are most stable. This is likely to be the case when the company is still being run by the first generation (ibid.) because conflicts and disagreements start to arise from the second generation onwards. In this respect, it is also a tool that might prevent family company weaknesses from developing at a later stage.

In particular, interviewees noted that CG guidelines should require a 'continuity plan', or a 'governance plan' in terms of where the family wishes to position itself in the medium to long-term. One Expert recalled a case when a family director introduced a family governance code to remediate the disputes that were taking place among the second and third generation family members. The 'code of family business' dealt with subjects such as the composition of the Board, education, and family share transfers, amongst others. Although the other family members resisted the implementation of the code by the family director, the Expert noted that "looking back, everyone acknowledged its beneficial effect".

\subsection{FAMILY FORA}

Documents including a family constitution are usually maintained by the family council (IFC, 2011). Nonetheless, since family assemblies are also responsible for formulating the mission and vision of the family (Farrugia, 2010), the family governance plan could also be maintained by the family assembly in the absence of a family council. Dialogue could therefore take place in a family assembly or a family council, where family members meet and discuss important family documents and information in relation to the business. This would contribute positively to good CG in family PICs.

In fact, the measure most agreed-to related to the establishment of a forum where family members can meet to provide and receive information in relation to the business. Both Experts and Cosecs agreed that establishing a governance body specifically for family members to meet and discuss would contribute to good CG. In this context, interviewees confirmed that the measure made sense in PAGE 28| Journal of Corporate Governance, Insurance, and Risk Management | 2020, VOL. 7, Series. 2 
principle, although to their knowledge this was not being practised in Malta.

\subsection{THE CHIEF EXECUTIVE OFFICER}

Experts generally agreed that allowing family members to form part of the senior management team would amount to good CG although Cosecs displayed a relatively neutral stance on this measure.

Respondents were generally neutral as to whether a family member should be allowed to act as CEO. In this context, interviewees noted that in principle "being a family member should not inherently disqualify anyone from being involved on the board or in senior management - the real issue is achieving the right balance." The question on whether the role of CEO should be occupied by a family member remains a contentious one. Although Baldacchino et al (2019) noted that a family CEO might put the Board in an uncomfortable position, one cannot preclude a family member from occupying this position simply because of an affiliation with the family.

The possibility for family members to occupy the role of CEO should therefore remain. As a counterbalance to the appointment of a family CEO, the Board should ensure that its assessment of the CEO is not influenced by the affiliation with the family. One could perhaps propose a system where a family CEO is counterbalanced by an independent, non-family chairperson leading the Board.

Leaving the possibility of combining the roles of a chairperson and CEO was not perceived as ideal in the context of a family PIC. In this respect, findings indicated that the two roles should be divided in a clear manner. Nevertheless, this also depends on the company's ownership structure. As evidenced by Braun \& Sharma (2007), the separation of the two roles tends to lose its desired effect on CG with a higher concentration of family ownership. This may suggest that separating the two roles in a founder family-owned company may not necessarily be beneficial. This argument gains even more weight when considering the positive association between founding family control and firm value (Mishra, Randoy, \& Jenssen, 2001).

\subsection{COMPOSITION OF THE BOARD}

The Boards of family PICs should not be composed of a majority of family members. As argued by Baldacchino et al. (2019), a suitable proportion of non-family independent directors is likely to contribute towards more transparency and accountability. Independence would be lost if the Board was composed of a majority of family members.

Findings indicate that there is a mixed feeling amongst participants on whether a family member PAGE 29| Journal of Corporate Governance, Insurance, and Risk Management | 2020, VOL. 7, Series. 2 
should act as chairperson of the Board. Several interviewees were

close to the territory favouring the appointment of an independent, non-family chairperson. The main reason given was that, because the chairperson is usually a strong founder member, there may be a higher risk of appointing 'yes' men with the aim of accommodating that dominant figure. This is also likely to happen because, as noted by Baldacchino et al (2019), family members tend to pursue the family's interest first. It is therefore acknowledged that a strong, dominant figure needs to be counterbalanced with independent individuals of sufficient calibre. On the other hand, it is acknowledged that the family cannot simply be side-lined, as noted by one Cosec:

"Having independent minded, non-executive directors that think outside the box and challenge the status quo is very important. But you cannot expect the one who gave birth to the 'baby' to just step aside."

This is totally understandable when considering that the family is the major shareholder and the driving force of the business. Therefore, a balance needs to be found on how the Board should be composed to ensure good governance.

Another consideration worth noting is the inter-generational effect on the CG system of a company. The CG system of a family PIC which is still being directed by the founding family does not have the same governance needs of a company being led by the second or third generations. Therefore, there may be a case for distinguishing between companies directed by a single family, most likely being the founder family, and companies directed by more than one inter-related families.

CG guidelines should recognise that a family PIC directed by the founding family is more likely to be in a stable position because the founder usually holds a firm grip on the direction of the company, as noted by Daspit et al. (2017) and Tagiuri and Davis (1996). In this respect, it was also noted that a concentration of power tends to positively affect a company's performance (Chen, 2012; Mishra, Randoy, \& Jenssen, 2001). Therefore, undermining a dominant figure by separating the roles of CEO and chairman may lose the desired effect the higher the concentration of family ownership (Braun \& Sharma, 2007). In this context, CG guidelines should expect a counterbalance to a dominant person that does not undermine their effectiveness.

On the other hand, a family company which is being taken over by the second or third generations is in a much more vulnerable position. The vulnerability can be attributed to several reasons. It may stem from a vacuum caused by the departure of a dominant figure. It may be the cause of emotional ties (ibid.) and the different backgrounds of family members that may be hard to reconcile in the board room. Thus, it was noted that the independent, non-family directors become extremely PAGE 30| Journal of Corporate Governance, Insurance, and Risk Management | 2020, VOL. 7, Series. 2 
important when "the second or third generations take over from the first generation". This is because in a family setting, "the emotions and egos are so strong that every business consideration becomes secondary", to the detriment of the company. In this respect, CG guidelines should expect a counterbalance which may only be achieved through the involvement of a non-family individual who takes on a leading and reconciliatory capacity.

This could be implemented by appointing an independent, non-family chairperson who may re-instil order and authority. By virtue of the chairperson's independence and his or her appointment by consensus, it would be hard for a family member or a family-appointed director to argue that a chairperson is acting in favour of one particular party. An independent chairperson would help to nullify any blinding emotions and prevent or help to resolve family disputes. This role would also introduce a sense of organisation and professionalism when the Board is mired with family clashes.

\subsection{TENURE OF FAMILY APPOINTMENTS}

Research participants generally agreed with prescribing the retirement age of family directors to enhance CG in family PICs. In this context, three Experts explained that this was very important because "there comes a time when you have to go" and give way to the next generations, especially when the first generation of family directors reach a certain age.

There might be several negative connotations associated with permanence of office. For instance, as noted by Baldacchino et al (2019), having top positions occupied indefinitely might lead to a culture that resists innovation. This mentality could be eradicated by defining the number of years a family CEO ought to remain in office.

Defining the retirement age of directors could also contribute to a more balanced composition of the Board. In this respect, although family directors are more likely to stay on beyond a certain age, distinguishing between family and non-family members might create more problems. This is also true for the post of CEO. Therefore, a system that inhibits long tenures and that is equally applicable to family and non-family members should be consistently applied across the board.

\subsection{FAMILY COMPETENCIES}

Research participants agreed to formally requiring a minimum level of education and work experience for family members intending to take on a directorship role. Indeed, it may be hard to reconcile the views of family directors having different educational backgrounds. The probability of disagreements owing to the different backgrounds was highlighted:

PAGE 31| Journal of Corporate Governance, Insurance, and Risk Management | 2020, VOL. 7, Series. 2 
"Some family directors have a professional educational background, while others have been working in the family company since they were teenagers. The clash is inevitable."

The different educational backgrounds of directors and managers breeds conflict, which is a distinctive weakness of family companies (KPMG, 2010; Mustakallio, 2002; Sarbah \& Xiao, 2015). This is due to the fact that directors with a different level of education may find themselves speaking two completely different languages. Sometimes, there is also a sense of superiority which two sorts of family directors seem to be entitled to: one for the academic and professional experience achieved and the other for the hands-on work experience gained on home ground - the family business. That is the extent to which "family ties blind any form of logic and professionalism".

Prescribing a minimum level of competencies required from directors is beneficial to CG. As pointed out by Baldacchino et al (2019), professional education and qualifications are necessary to ensure that competent individuals are appointed. This requirement would also help to identify any training needs. Nonetheless, it is extremely difficult to find a balance in a family company setting. For instance, it would be hard to prove that a family member is not fit for purpose unless there are formal procedures for assessing competence. On the other hand, it would be counterproductive to overregulate the appointment of directors because ultimately the appointees must be trusted by the family.

Therefore, although most participants agreed with prescribing a minimum level of education and experience for family directors, a more moderate approach could be to require a mentoring or training programme for all appointed directors (whether family or non-family) who do not have a minimum level of competency. This would give an opportunity for young family members to expand their business experience and qualifications without compromising the competence of the Board. Training programmes are likely to be effective from an early stage before directors are appointed to the Board. For instance, family-constituted bodies such as a family council provide an ideal place to mandate a training programme for potential board members as noted by Weiste (2013). The training programmes should be adequately documented to ensure transparency and accountability.

\subsection{CONDUCT}

Instilling a culture that requires some form of continuous professional education for family directors is seen as a favourable measure contributing towards better CG. In this respect, the Guidelines should widen the scope to include specific adequate training for directors and not only for managers and employees. This measure is likely to be effective because it may help less experienced directors whilst bridging the gap with other directors having a professional background. This may also go PAGE 32| Journal of Corporate Governance, Insurance, and Risk Management | 2020, VOL. 7, Series. 2 
some way to addressing the conflicts arising from this gap.

Although laying down grounds for termination for family management and family directors was supported by most respondents, it is to be noted that a system that distinguishes between the conduct of family and non-family members across all levels of the organisation will tend to create more challenges. In much the same vein, defining penalties for non-compliance should be equally applicable to family and non-family members. Moreover, the system should be consistently applied consistent and enforced across the board by independent directors.

\subsection{FAMILY REMUNERATION}

The validation of remuneration levels in line with market benchmarks by external consultants would contribute to more transparency and better CG of family PICs that are not expected to have a remuneration committee. This would also help to prevent the unequal treatment of family and nonfamily members, which is a recurring feature in family-owned companies (Daspit et al, 2018; Debicki, 2017; Verbeke \& Kano, 2012). Documenting these processes would also improve transparency and accountability towards all relevant stakeholders.

\subsection{PERFORMANCE EVALUATION}

In a family setting, it is acknowledged that the principle that all directors should regularly review the performance of senior management might not be happening in reality. This is also very much related to the reality that the Board might work around the requirement to appoint 'independent' directors. The counterbalance provided by an independent, non-family chairperson heading the Board is equally relevant to counterbalance other senior executives and not only the CEO. This would also help to counter the disparate performance evaluation of family and non-family members, a weakness which was highlighted by various researchers. Performance reviews should also extend to all board directors irrespective of whether they are affiliated with the family.

\subsection{THE NEUTRAL SANCTITY OF THE FAMILY PIC}

The portrayal of a company's interest as seemingly distinct from, or misaligned to, the interests of its shareholders may be somewhat hard to imagine. This is because the company is a creation of its shareholders aimed, first and foremost, for their benefit.

It is therefore ironic (and equally curious) that a significant number of participants have PAGE 33| Journal of Corporate Governance, Insurance, and Risk Management | 2020, VOL. 7, Series. 2 
distinguished between the protection afforded to the interest of the 'company' and its 'shareholders' as though these could be ranked in order of priority, hence allowing for a clearer distinction of the two interests. More specifically, some respondents believed that the long-term interests of the company should be placed before the short-term interests of a dominant group of shareholders such as a family.

Considering the fundamental and most basic tenet that a company is supposed to act in the interest of its shareholders, why did interviewees distinguish between the interest of a company and its shareholders? In the context of a dominant group of family shareholders a plausible reason for this distinction could be that, for the purposes of this study, a company is not simply a family company, but also a public interest company. In other words, the public dimension of a family company may render the distinction between the interests of a company and its shareholders more apparent.

This is not to say that the interest of shareholders should not be paramount, but that in the context of the peculiarities displayed by family companies, the going concern of a family company with a public interest dimension places foremost in formulating CG guidelines. The distinctive attributes of family companies, such as concentration of power (Daspit, et al. 2017; Tagiuri \& Davis, 1996), weaknesses such as suppressed growth (Baldacchino et al, 2019; Le-Breton-Miller \& Miller, 2009;), and a high probability of conflict (KPMG, 2010; Mustakallio, 2002; Sarbah \& Xiao, 2015) render the family PIC a more fragile creature compared to its non-family peers. Using Grech's frame of thought (2014) in the context of the research findings, one can argue that the inherent characteristics of a family firm in a public dimension sanctify the company. In other words, the company's interests in terms of its business continuity should be given more weight in view of the family and public interest dynamics.

While recognising this concept would protect the interests of family shareholders because they stand to gain most from business continuity, it would also protect the public interest from short-termism, bad management, and conflicts of interest. Therefore, at some point, the interests of the family and the public converge for the proper continuation of the company. Figure 2 illustrates the intersection of these interests. 


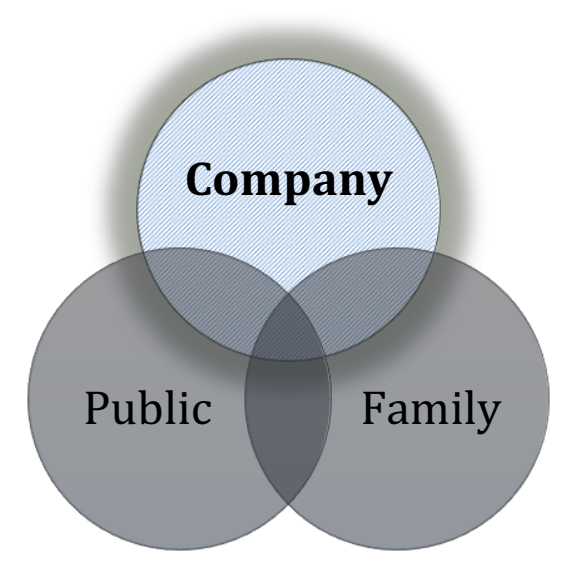

Figure 2- The Neutral Sanctity of the Family PIC

Several interviewees believed that CG guidelines should place the interests of outside stakeholders before the interests of shareholders especially in the case of family PICs. A guiding principle needs to spell out the importance of other stakeholders' interests, especially in the case of companies dominated by families. The argument

may be relevant when considering that controlling shareholders can defend their interests in the board room, whilst other stakeholders cannot.

\subsection{SHARE TRANSFERS}

As highlighted by Mustakallio (2002), most interviewees noted that shares in a family business are generally illiquid. The ownership of family businesses does not change hand very frequently and is most likely triggered by extraordinary events such as the demise of a family member or family disputes. A share transfer plan that is triggered immediately after the occurrence of extraordinary events ensures certainty and business continuity. Moreover, a share transfer plan that does not necessarily target family members is a very important element in order to preserve the continuity of the company.

In this respect, pre-emption rights that are reserved exclusively to family members might bring a 'deadlock' situation. This is because family members not interested in the company and seeking to liquidate their share might not want to cede their portion to the other family simply because emotions override any other consideration. A more efficient system can only be achieved if there is an allencompassing strategy of where the family wants to position itself vis-à-vis the business. This could be achieved by formally documenting the family's plan. A family forum where members can discuss these plans would also be ideal.

PAGE 35| Journal of Corporate Governance, Insurance, and Risk Management | 2020, VOL. 7, Series. 2 
If a family wants to remain in control, a share transfer plan intended to expedite share transfers among family members in extraordinary times would ensure continuity of business. In the case where the family wants to exit the business, a share transfer plan that ropes in other minority shareholders or third parties would be relevant for the continued existence of the company. Respondents were generally in agreement with principles such as establishing a pre-determined process for buying out family shareholders and giving the right of first refusal to the minority owners of the company. It was therefore acknowledged that these could have a positive impact on the company's continuity.

\subsection{THE CONSERVATION OF CAPITAL}

The conservation of capital reserves in a family PIC is of utmost importance to ensure the continued financial viability of the company and to avoid short-termism. Guidelines ought to highlight this aspect specifically by introducing the concept of a minimum maintenance level which would be determined on a company-by-company basis. This measure could help to reconcile the different family interests by creating a balance between those seeking a dividend return and other families whose primary source of income is the family business. Moreover, this would help to preserve the continuation of the company.

\section{CONCLUSIONS}

The authors conclude that the Guidelines for PICs adopt a one-size-fits-all approach which in most cases is not relevant to the needs of family PICs in Malta. Guidelines should reflect the family companies' need to formally institute family meetings to improve the communication among members of the same family, between different families, and most importantly between the family and the company's structures. There is a need for family members to formally document a family governance plan including a family constitution. Moreover, there needs to be clearer guidance on the composition of the Board given the peculiarities of family PICs and the changeover from one generation to the next.

Clearer guidance should be provided on the process of appointing independent directors and engaging senior managers in the context of dominant family interests. In particular, the required competencies of directors should be highlighted. Guidance should be provided on how to determine compensation levels and monitor conduct and performance in a more transparent way. Family PICs should properly document the selection criteria and the Board's assessment for appointing independent directors and CEOs. A family PIC should document the basis for concluding that a director or a CEO is an independent, non-family person. This should increase accountability and make the processes more transparent.

PAGE 36| Journal of Corporate Governance, Insurance, and Risk Management | 2020, VOL. 7, Series. 2 
This study also concludes that the Board should endeavour to appoint an independent, non-family chairperson when the power is distributed amongst multiple families. This may be the case when the Board is represented by second and third generation family directors. The Board should establish and set out in writing a clear division of roles and responsibilities between the running of the Board and the executive responsibility for the running of the company particularly in the case of dispersed family shareholding structures (second and third generations).

The competencies required from directors to be appointed on the Board may vary from one company to another. Nonetheless, this study concludes that determining a minimum level based on companyspecific criteria such as experience and qualifications would serve to identify any gaps required for the positions. The Board should address any gaps identified. For example, it could require a handholding period for prospective directors especially in the case of junior family directors. Examples of good practices include mandatory training or assistance from external consultants during the transition period. This should start from an early stage, possibly at the level of the family assembly or family council. Furthermore, the Board should ensure that there is adequate ongoing training for directors and not just for management and employees.

The authors also conclude that the continued existence of a family company is more important in the context of public interest companies. Because of the family and public dimensions, the company per se takes on a more distinct autonomy (and sanctity) that transcends its existence as a mere legal identity. Guidelines should also help family PICs to balance the duties owed to shareholders and the public in an equitable manner such that the dominant influence of family interests does not unfairly step on those of other stakeholders.

It is recognised that the concentrated shareholding patterns in family companies allow more control and oversight over management. But this cannot happen at the expense of other interests. Most importantly, it cannot happen at the expense of the communal interest in the case of family public interest companies.

This study focuses exclusively on Maltese family public interest companies. Although every effort has been made to conduct a comprehensive study on the subject matter, it remains that the study is subject to a number of limitations. All participants in the study were Maltese and the findings of the study are therefore limited to Malta. It is inevitable that the views expressed are influenced by the culture, regulations and systems within the country, particularly in a small state such as Malta. The study is also subject to the limitations that are inherently associated with the research methods that were adopted for the purpose of this study.

\section{REFERENCES}

PAGE 37| Journal of Corporate Governance, Insurance, and Risk Management | 2020, VOL. 7, Series. 2 
Baldacchino, P. J., Gauci, A., \& Grima, S. (2019). Family Influence in Maltese Listed Companies: The Implications on CG. International Journal of Economics and Business Administration, 85-112.

Berle, A., \& Means, G. (1932). The Modern Corporation and Private Property. New York: Macmillan.

Braun, M., \& Sharma, A. (2007, June). Should the CEO Also Be Chair of the Board? An Empirical Examination of Family-Controlled Public Firms. Family Business Review, pp. 111-126.

Brenes, E., Madrigal, K., \& Requena, B. (2011). Corporate Governance and Family Business Performance. Journal of Business Research, pp. 64(3), p. 280-285.

Cacciotti, G., \& Ucbasaran, D. (2017). Blockholder Structures and Power Mechanisms in Family Firms. Entrepreneurship Theory and Practice, 1-7.

Cadbury, S. A. (2000). Family Firms and Their Governance: Creating Tomorrow's Company from Today's. Egon Zehnder International.

Chen, L. (2012). The Effect of Ownership Structure on Firm Performance. Dissertation - Msc in Finance \& International Business, Aarhus School of Business. Aarhus University: http://pure.au.dk/portal/files/48424135/The_Effect_of_Ownership_Structure on_Firm_Performance_Chen_Luzhen_2012.pdf [Accessed 01/02/2019].

Chrisman J. J., C. J.-M. (2018). Governance Mechanisms and Family Firms.

Entrepreneurship Theory and Practice, Vol. 42(2) p.17

Chrisman, J., \& Holt, D. (2016). Beyond Socioemotional Wealth: Taking another Step toward a Theory of the Family Firm. Management Research, 14(3), 279-287.

Committee on The Financial Aspects of Corporate Governance. (1992). Report of the Committee on The Financial Aspects of Corporate Governance. London: Gee \& Co. Ltd.

Creswell, J. W. (2015). Concise Introduction to Mixed Methods Research. USA: SAGE Publications, Inc.

Creswell, J., \& Vicki L. Piano Clark. (2011). Designing and Conducting Mixed Methods Research. Thousand Oaks, CA: SAGE Publications.

Daspit, J., Chrisman, J., Sharma, P., Pearson, A., \& Long, R. (2017). A Strategic Management Perspective of the Family Firm: Past Trends, New Insights, and Future Directions. Journal of Managerial Issues, 29(1), pp. 6-29.

Daspit, J., Madison, K., Barnett, T., \& Long, R. (2018). The Emergence of Bifurcation Bias from Unbalanced Families: Examining HR Practices in the Family Firm using Circumplex Theory. Human Resource Management Review, 18-32.

Debicki, B. V. (2017). Socioemotional Wealth and Family Firm Performance: A Stakeholder Approach. Journal of Managerial Issues, 29(1), pp.82-111.

Donnelley, R. (1988, Winter). The Family Business. Family Business Review, pp. Vol 1, p.440. 
ecoDa. (2010, ecoda.org/uploads/media/GUIDANCE_-_2010_CG_for_Unlisted_-_EU.pdf [Accessed 29 August 2018]). Corporate Governance Guidance and Principles for Unlisted Companies in Europe.

Farrugia, N. (2010). The Issue of Corporate Governance in Family-Run Businesses. University of Malta..

Goh, C., Rasli, A., \& Khan, S. (2014). CEO duality, board independence, corporate governance and firm performance in family firms: Evidence from the manufacturing industry in Malaysia. Asian Business \& Management, 13(4), pp.333 - 357.

Grech, E. (2014). The Role and Obligations of Non-Executive Directors under Maltese Law. Corporate Board: Role, Duties \& Composition, 71-83.

Habbershon, T., Nordqvist, M., \& Zellweger, T. (2010). Transgenerational Entrepreneurship: Exploring Growth and Performance in Family Firms across Generations. Cheltenham, England: Edward Elgar.

Hirsch, R. (n.d.). Decoding Family Businesses - The Potential of Corporate Governance Guidelines for Family Businesses. University of Auckland.

Hirsch, R. J. (2013). The Evolution and Role of Corporate Governance Guidelines for Family Businesses: A Structural Investigation. The University of Auckland.

Hnilica, J., \& Machek, O. (2015). Toward a Measurable Definition of Family Business: Surname Matching and its Application in the Czech Republic. International Advances in Economic Research, 21(1), pp.119-120.

International Finance Corporation (IFC). (2011). IFC Family Business Governance Handbook. https://www.ifc.org/wps/wcm/connect/topics_ext_content/ifc_external_corpo rate_site/ifc $+\mathrm{cg} /$ resources/guidelines_reviews + and + case + studies/ifc + family $+b$ usiness+governance+handbook [Retrieved 7 September 2018].

INTES, FBN \& Die Familienunternehmer - ASU. (2004), http://www.kodex-fuerfamilienunternehmen.de/images/Downloads/Kodex_englisch_2015.pdf). The Governance Code for Family Businesses. INTES Akademie für Familienunternehmen GmbH, F.B.N. Deutschland.

Jain, B., \& Shao, Y. (2015). Family Firm Governance and Financial Policy Choices in Newly Public Firms. Corporate Governance: An International Review, 23(5), pp. 452-468.

Kepner, E. (1983). The family and the Firm: A Coevolutionary Perspective. Organisational Dynamics, 12: $57-70$.

KPMG. (2010). Retrieved from Family Business Australia: https://www.fambiz.com.au/wpcontent/uploads/Constructing-a-Family- Constitution-KPMG.pdf

Kraiczy, N. (2013). Innovations in Small and Medium-Sized Family Firms. An Analysis of Innovations Related Top Management Team Behaviours and Firm-Specific Characteristics. Vallendar: Springer Gabler.

Lansberg, I. (1983, Summer). Managing Human Resources in Family Firms: The Problem of Institutional Overlap. Organizational Dynamics, pp. XII 39-46. 
Le-Breton-Miller, I., \& Miller, D. (2009). Agency vs. Stewardship in Public Family Firms: A Social Embeddedness Reconciliation. Entrepreneurship Theory and Practice, 33(6) pp. 1169-1191.

Lee, J. (2006). Family Firm Performance: Further Evidence. Family Business Review, 19(2), 103-114.

MFSA. (2001). Code of Principles of Good Corporate Governance for Listed Entities.

Retrieved from Malta Financial Services Authority: https://www.mfsa.com.mt/wpcontent/uploads/2019/02/Code-of-Principles- of-Good-Corporate-Governance-for-Listed-

Entities.pdf [Accessed 30 August 2018]

MFSA. (2006). Corporate Governance Guidelines for Public Interest Companies. Retrieved from Malta Financial Services Authority: https:/www.mfsa.com.mt/pages/viewcontent.aspx?id=365 [Accessed 30August 2018]

MFSA. (2014). Corporate Governance Manual for Directors of Investment Companies and Collective Investment Schemes. Retrieved from Malta Financial Services

Authority: https://www.mfsa.com.mt/wp-content/uploads/2019/02/MFSA- Corporate-GovernanceManual-Sept-2014.pdf [Accessed 30 August 2018]

Mishra, C., Randoy, T., \& Jenssen, J. I. (2001). The Effect of Founding Family Influence on Firm Value and Corporate Governance. Journal of International Financial Management and Accounting, 235-259.

Morck, R., \& Yeung, B. (2003). Agency Problems in Large Family Business Groups. pp. 367-382.

Morck, R., \& Yeung, B. (2004). Special Issues Relating to Corporate Governance and Family Control. Retrieved from The World http://documents.worldbank.org/curated/en/294611468761962776/Special- issues-relating-tocorporate-governance-and-family-control [Accessed 16January 2019]

Muscat, A. (2007). Principles of Maltese Company Law. Malta: Malta University Press.

Mustakallio, M. (2002). Contractual and Relational Governance in Family Firms: Effects on Strategic Decision-Making Quality and Firm Performance. Doctoral Dissertation. Helsinki: Helsinki University of Technology.

Mustakallio, M., Autio, E., \& Zahra, S. (2002). Relational and Contractual Governance in Family Firms: Effects on Strategic Decision Making. Family Business Review, pp. 15(3), p.205-222.

Neubauer, F., \& Lank, A. (1998). The Family Business: Its Governance for Sustainability. London: Macmillan Press Ltd.

OECD. (2015). G20/OECD Principles of Corporate Governance. OECD Publishing. Retrieved from OECD iLibrary: http://dx.doi.org/10.1787/9789264236882-en

Riinvest Institute. (2015). Governance Guide for Family-Owned Businesses. Riinvest Institute. Sarbah, A., \& Xiao, W. (2015). Good Corporate Governance Structures: A Must for Family Businesses. Open Journal of Business and Management, 3, pp.40-57. 
Shleifer, A., \& Vishny, R. (1997). A Survey of Corporate Governance. The Journal of Finance, 737-783.

Tagiuri, R., \& Davis, J. (1996). Bivalent Attributes of the Family Firm. Family Business Review.

Taylor Wessing. (2014). The Family Constitution Guide. Retrieved from Taylor Wessing: https://united-kingdom.taylorwessing.com/.../get/88/the-family-constitution- guide.pdf [Retrieved 29 August 2018]

Thomas, J. (2001). Effective Processes in the Family Business to Provide for Ownership Transfer or Exit. 12th Annual World Conference. Rome: Family Business Network.

Verbeke, A., \& Kano, L. (2012). The transaction cost economies theory of the family firm: Family-based human asset specificity and the bifurcation bias.Entrepreneurship Theory and Practice, 36(6) 1183-1205.

Weiste, L. (2013). The Role of Family Governance and Family Councils as a Success Factor for Long Lasting Family Companies. Master's Thesis. Aalto University School of Business. Available at: https://slidex.tips/download/the-role-of- family-governance-and-family-councils-as-a-success-factorfor-long-1 [Accessed 2nd December 2018].

Working Group on Corporate Governance (Malta Stock Exchange). (2001). Report of the Working Group on Corporate Governance. Malta.

Yeh, Y.-H., Lee, T.-S., \& Woidtke, T. (2001). Family Control and Corporate Governance: Evidence from Taiwan. International Review of Finance, pp. 21-48.

Zahra, I. (2017). An Analysis into the Definition of a 'Family Business' in the Family Business Act. Term Paper, Faculty of Laws, University of Malta.

Zellweger, T., \& Kammerlander, N. (2015, February). Family, Wealth and Governance: An Agency Account. Retrieved from https://www.alexandria.unisg.ch/238997/1/ETP-WealthGovernance-Finalpreprint.pdf [Retrieved 2 February 2019]

Zellweger, T., Nason, R., \& Nordqvist, M. (2011, November 7). From Longevity of Firms to Transgenerational Entrepreneurship of Families: Introducing Family Entrepreneurial Orientation. Family Business Review, pp.1-20. 